\title{
INVESTIGATION OF THE GROUNDWATER SUITABILITY FOR IRRIGATION PRACTICES IN AN ARID REGION: CASE STUDY
}

\author{
Ahmed Murad \\ Department of Geology, UAE University, UAE
}

Received 2013-10-21, Revised 2014-01-08; Accepted 2014-01-25

\begin{abstract}
Groundwater is an important source of acceptable water for irrigation in the arid regions and in particular in the United Arab Emirates (UAE). Demand for groundwater is increasing in the UAE due to population growth and significant economic advancement associated with political stability. As agricultural practices are the main land use in Al Hayer area, southeast UAE, majority of extracted groundwater from major aquifer is used to meet the increasing demands of irrigation. This study is aimed to assess the suitability of groundwater in the study area for irrigation practices using classifications of Sodium Adsorption Ratio (SAR), Soluble Sodium Percentage (SSP), Magnesium Adsorption Ratio (MAR) as magnesium hazard and Residual Sodium Carbonate (RSC). In addition to that, the quality is assessed using the Total Dissolved Solids (TDS) and Electrical Conductivity (EC) of collected groundwater samples. Assessing the quality of groundwater in the region will help the decision makers in determining appropriate actions and using the conventional management tools to protect groundwater from the possible contamination. The chemical results indicate that the groundwater of the study area contains excess of $\mathrm{Na}^{+}$and $\mathrm{Mg}^{+2}$. This is related to the weathering of Oman Mountains which are located to the east of the study area. The data analyses of salinity hazard suggested that about $44 \%$ of collected groundwater samples from the entire region are grouped as very high salinity and are not suitable for irrigation and about $56 \%$ are grouped as high salinity which is doubtful to be used for irrigation. The calculations of SAR reveal that the groundwater of the study area is good to excellent for crop production. While, the calculated magnesium hazard suggests that all samples are not suitable for irrigation purposes. The SAR-EC plot presents two groups of sampling points. The first group of groundwater can be used for irrigation of most crops in almost all soils, however, the second group of groundwater is not suitable for irrigation under normal conditions.
\end{abstract}

Keywords: Groundwater, Irrigation Water, Salinity, SAR, United Arab Emirates

\section{INTRODUCTION}

Water is an essential bio-resource for the entire life. The freshwater resources are less than $1 \%$ and about $0.01 \%$ of all water present on the earth (Hakim et al., 2009 and Shiklomanov, 1993). The United Arab Emirates (UAE) is an arid region and one among those countries in the Middle East and North Africa (MENA) facing serious shortages in water resources to meet the demands of rapid developments in the country. Therefore, sustaining water resources in the UAE is a major concern for the decision makers and scientists. Previously, groundwater was considered as a major source of water in the UAE and in particular the investigated area. With the time, the desalinated water became a major source for different domestic, agricultural and industrial uses.

Groundwater is one of the conventional water resources in the world. Human activities and civilizations were concentrated around the sources of water. In UAE, these unplanned human activities and increasing economical developments applied huge stress on groundwater resources. Agricultural practices are the main land use in $\mathrm{Al}$ Hayer area, which is situated to the southeast of the UAE. Successful agrictural practices requries high quality irrigated water. More than $70 \%$ of the groundwater consumed by agriculture and quality of groundwater is a 
major concern for farmers in the investigated area. Agricultural practices increased over last few decades due to governmental support and this was reflected in changing the size of cultivation in the investigated area. The total irrigated area in the region was 69,142 and $136 \mathrm{Km}^{2}$ in 1996, 2000 and 2004, respectively.

High salinity groundwater is one of the major constrains in agro-well farming in arid region (Kendaragama, 2000). Irrigation using poor quality water could bring undesirable elements to the soil which might affect the soil fertility and change its physical and chemical properties (Nishanthiny et al., 2010 and Ibrahim et al., 2012). Saline water used for irrigation can reduce or even prohibit crop production, while low salinity in irrigation water might reduce water infiltration, which indirectly affects the crop production (Grattan, 2002). In order to avoid associated problems and optimize the crop production, it is essential to understand the quality of irrigation water. This study is designed to assess the toxicity of groundwater and investigate the suitability of it in $\mathrm{Al}$ Hayer area for sustainable agricultural practices using different methods.

\section{MATERIALS AND METHODS}

The UAE is located in the southeastern part of the Arabian Peninsula between latitudes $22^{\circ} 40^{\prime}$ and $26^{\circ} 00^{\prime}$ $\mathrm{N}$ and longitudes $51^{\circ} 00^{\prime}$ and $56^{\circ} 00^{\prime} \mathrm{E}$. The study area namely $\mathrm{Al}$ Hayer is situated within the northern part of $\mathrm{Al}$ Ain area and northeastern part of Abu Dhabi Emirate (Fig. 1) and the landmass of the study area is about $20 \mathrm{Km}^{2}$.

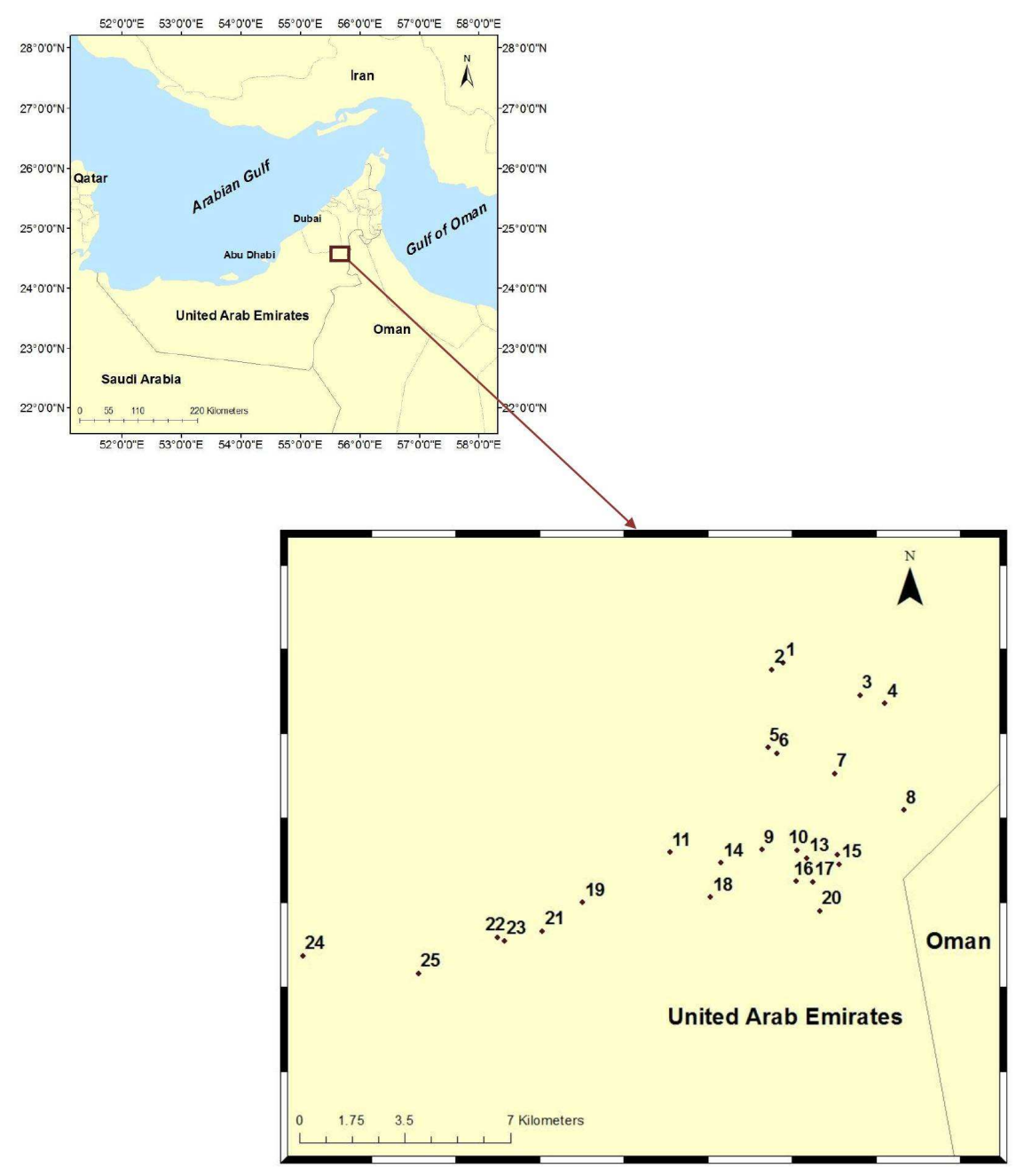

Fig. 1. Map showing the location of the study area and sampling points 
The natural climatic conditions have a negative impact on the availability of groundwater in the area. Based on rainfall data from 1995-August 2007 obtained from the Meteorological Department of National Authority of Communication- UAE, the rainfall amount in Al Ain area varied between $0.2 \mathrm{~mm}$ in April 1998 to 58.8 $\mathrm{mm}$ in April 2003. The maximum annual average of rainfall in Al Ain region was $0.5 \mathrm{~mm}$ in 1996, whereas the minimum annual average was nearly zero in 2001 . The average maximum air temperature of $\mathrm{Al}$ Ain area varied from 34.1 to $36.3^{\circ} \mathrm{C}$. However, sometimes, the temperature can reach up to $40^{\circ} \mathrm{C}$. The average minimum air temperature of $\mathrm{Al}$ Ain region varied from 21.4 to $23.1^{\circ} \mathrm{C}$.

The study included 25 groundwater wells collected from the entire study area from east where the recharge occurs to the west where the discharge occurs (Fig. 1).

The physical parameters of $\mathrm{pH}$, temperature, Total Dissolved Solids (TDS) and Electrical Conductivity (EC) for the collected groundwater samples were measured in the field. The collection of groundwater samples was done after the removal of the stagnant water in the pipes and the contaminated water. High density 1 L PVC two bottles were used for sampling in which each sampled bottle was washed with deionized water and then with water from sampled well. Each bottle was filled up to the brim and immediately sealed to avoid exposure to air (Clesceri et al., 1989). Samples used for anion analyses $\left(\mathrm{HCO}_{3}{ }^{-}\right.$ $\& \mathrm{CO}_{3}^{-2}$ ) were stored at a temperature below $4^{\circ} \mathrm{C}$ before the analyses at the laboratory. However, samples used for cation anlayses $\left(\mathrm{Na}^{+}, \mathrm{K}^{+}, \mathrm{Ca}^{+2}\right.$, $\mathrm{Mg}^{+2}$ ) were acidifed to $\mathrm{pH}<2$ using nitric acid $65 \%$ (Appelo and Postma, 1999), . The collected water samples were transported to the Hydrogeology Laboratory at UAE University for further analyses. The samples were analyzed for Sodium $\left(\mathrm{Na}^{+}\right)$, Potassium $\left(\mathrm{K}^{+}\right)$, Calcium $\left(\mathrm{Ca}^{+2}\right)$, Magnesium $\left(\mathrm{Mg}^{+2}\right)$, Carbonate $\left(\mathrm{CO}_{3}^{-2}\right)$ and Bicarbonate $\left(\mathrm{HCO}_{3}{ }^{-}\right)$. Different parameters were calculated based on the results of the chemical analyses of groundwater samples for suitability for irrigation purposes. The classifications of groundwater for irrigation purposes were obtained using the Sodium Adsorption Ratio (SAR), Soluble Sodium Percentage (SSP), Magnesium Adsorption Ratio (MAR) as magnesium hazard and Residual Sodium Carbonate (RSC). The equations for the above parameters are as follows (Domenico and Schwartz, 1990; Eaton, 1950; RSL, 1954; Szabolcs and Darab, 1964; Todd, 1980):

$$
\begin{gathered}
\mathrm{SAR}=\mathrm{Na}^{+} / \sqrt{ }\left[\left(\mathrm{Ca}^{+2}+\mathrm{Mg}^{+2}\right) / 2\right] \\
\mathrm{SSP}=\left[\left(\mathrm{Na}^{+}+\mathrm{K}^{+}\right) /\left(\mathrm{Ca}^{+2}+\mathrm{Mg}^{+2}+\mathrm{Na}^{+}+\mathrm{K}^{+}\right)\right] * 100 \\
\text { MAR }=\left[\left(\mathrm{Mg}^{+2}\right) /\left(\mathrm{Ca}^{+2}+\mathrm{Mg}^{+2}\right)\right]^{* 100} \\
\mathrm{RSC}=\left(\mathrm{CO}_{3}^{-2}+\mathrm{HCO}_{3}^{-}\right)-\left(\mathrm{Ca}^{+2}+\mathrm{Mg}^{+2}\right)
\end{gathered}
$$

All concentrations are expressed in meq/L.

In addition to that, correlation analyses between different quality indicators to understand different process that affect the quality of irrigation water was done.

\section{RESULTS}

The physical and chemical analyses of collected groundwater samples from the study area are presented in Table 1. The $\mathrm{pH}$ of collected groundwater ranges from 7.9 to 8.3 indicating that the groundwater of the investigated area is characterized by alkaline tendency. The temperature of groundwater of the study area varied between 29 to $33^{\circ} \mathrm{C}$. The range of EC in groundwater samples spans between 462 to $7155 \mu \mathrm{S} / \mathrm{cm}$. The TDS values extend from 206 to $3650 \mathrm{mg} \mathrm{L}^{-1}$. The chemical results showed that the concentrations of $\mathrm{Ca}^{+2}, \mathrm{Mg}^{+2}, \mathrm{Na}^{+}$and $\mathrm{K}^{+}$in groundwater range at $0.6-9.6,1.3-17.2,2.2-43.5$ and 0.08-1.02 meq $\mathrm{L}^{-1}$, respectively. The $\mathrm{HCO}_{3}{ }^{-}$ concentration in groundwater shows a range from 1.6 to 10.6 meq $\mathrm{L}^{-1}$.

The SAR for groundwater of the study area ranged from 2.6 to 15.7 and the calculated SSP for water samples varied from 52.3 to 78.7. The values of MAR and RSC were in the range of 87.6 to 100 and -6.98 to 2.9 , respectively. The RSC values for most of the water samples had negative values suggesting that the dissolved calcium and magnesium are higher than the bicarbonate contents in those groundwater samples. Based on MAR criterion, all samples are unsuitable for irrigation, while based on SAR, all samples are in excellent and good conditions (Table 2). AquaChem program (V 5.1) is used to construct Wilcox diagram, which is the relationship between salinity hazard expressed in EC $(\mu \mathrm{S} / \mathrm{cm})$ and sodium hazard expressed in SAR.

The correlation coefficients for the relationships among EC, SAR, MAR, SSP and RSC were determined (Table 3). It was noticed that EC was correlated with SAR and RSC with correlation coefficient of 0.83 and 0.76 , respectively. 
Ahmed Murad / American Journal of Environmental Science 10 (1): 1-7, 2014

Table 1. Physical and chemical parameters of collected groundwater samples

\begin{tabular}{llllllllll}
\hline Sample No. & $\mathrm{X}$ & $\mathrm{Y}$ & $\mathrm{pH}$ & $\mathrm{T}$ & $\mathrm{Na}(\mathrm{meq} / \mathrm{L})$ & $\mathrm{K}(\mathrm{meq} / \mathrm{L})$ & $\mathrm{Ca}(\mathrm{meq} / \mathrm{L})$ & $\mathrm{Mg}(\mathrm{meq} / \mathrm{L})$ & $\mathrm{HCO}(\mathrm{meq} / \mathrm{L})$ \\
\hline 1 & 373039 & 2724512 & 8.3 & 32.1 & 5.5 & 0.2 & 0.8 & 1.6 & 1.70 \\
2 & 372680 & 2724284 & 8.3 & 31.3 & 5.4 & 0.2 & 0.8 & 1.7 & 2.00 \\
3 & 375342 & 2723411 & 8.2 & 33.0 & 8.6 & 0.2 & 0.9 & 1.5 & 3.70 \\
4 & 376097 & 2723141 & 7.9 & 31.5 & 7.0 & 0.2 & 2.0 & 4.4 & 3.80 \\
5 & 372553 & 2721715 & 7.9 & 32.8 & 13.7 & 0.3 & 2.4 & 7.7 & 4.70 \\
6 & 372813 & 2721529 & 8.1 & 29.8 & 8.0 & 0.2 & 1.3 & 3.7 & 3.20 \\
7 & 374550 & 2720841 & 8.0 & & 13.1 & 0.2 & 1.6 & 4.7 & 5.00 \\
8 & 376643 & 2719619 & 8.3 & 33.9 & 2.2 & 0.1 & 0.6 & 1.3 & 1.60 \\
9 & 372328 & 2718351 & 8.2 & & 7.7 & 0.2 & 1.5 & 4.4 & 4.20 \\
10 & 373392 & 2718325 & 8.0 & 32.2 & 8.9 & 0.2 & 1.6 & 3.9 & 7.10 \\
11 & 369551 & 2718295 & 8.1 & 32.0 & 9.5 & 0.3 & 2.1 & 5.8 & 3.10 \\
12 & 374623 & 2718171 & 8.1 & 31.7 & 5.0 & 0.1 & 1.4 & 3.3 & 2.90 \\
13 & 373698 & 2718059 & 8.1 & 31.2 & 6.7 & 0.2 & 1.5 & 3.8 & 4.70 \\
14 & 371086 & 2717928 & 8.2 & 31.7 & 10.7 & 0.3 & 2.1 & 6.4 & 6.20 \\
15 & 374675 & 2717844 & 8.0 & 32.2 & 7.0 & 0.1 & 1.1 & 2.3 & 4.10 \\
16 & 373362 & 2717303 & 8.3 & 31.0 & 8.3 & 0.3 & 1.7 & 4.2 & 3.70 \\
17 & 373853 & 2717284 & 8.3 & 31.2 & 7.7 & 0.3 & 2.4 & 5.6 & 6.60 \\
18 & 370758 & 2716801 & 8.1 & 31.4 & 10.4 & 0.3 & 2.3 & 5.4 & 7.00 \\
19 & 366882 & 2716662 & 7.9 & 30.1 & 38.5 & 1.0 & 4.6 & 13.3 & 10.6 \\
20 & 374066 & 2716323 & 8.2 & 29.9 & 8.1 & 0.2 & 0.7 & 2.3 & 3.10 \\
21 & 365662 & 2715734 & 7.9 & 30.6 & 41.4 & 0.9 & 5.9 & 12.3 & 6.10 \\
22 & 364290 & 2715548 & 7.9 & 30.1 & 43.5 & 0.9 & 9.6 & 17.2 & 5.90 \\
23 & 364496 & 2715421 & 8.0 & 31.8 & 35.8 & 0.7 & 6.0 & 9.7 & 8.70 \\
24 & 358392 & 2714993 & 8.0 & 30.1 & 40.7 & 0.9 & 9.4 & 13.9 & 7.90 \\
25 & 361888 & 2714381 & 8.0 & 31.5 & 34.8 & 0.0 & 6.5 & 12.8 & 8.00
\end{tabular}

Table 2. Classification of groundwater for irrigation based on different criteria

\begin{tabular}{|c|c|c|c|c|c|c|c|c|c|c|}
\hline Sample No. & TDS (mg/L) & $\mathrm{EC}(\mu \mathrm{S} / \mathrm{cm})$ & SSP & Class & MAR & Class & SAR & Class & RSC & Class \\
\hline 1 & 417 & 938.5 & 70.0 & Doubtful & 87.6 & Unsuitable & 5.7 & Excellent & -0.2 & Good \\
\hline 2 & 451 & 1024.5 & 69.3 & Doubtful & 88.1 & Unsuitable & 5.6 & Excellent & 0.1 & Good \\
\hline 3 & 582 & 1296.5 & 78.7 & Doubtful & 88.7 & Unsuitable & 9.4 & Excellent & 2.0 & Doubtful \\
\hline 4 & 765 & 1706.5 & 52.8 & Permissible & 94.9 & Unsuitable & 4.5 & Excellent & -0.9 & Good \\
\hline 5 & 1409 & 3150.0 & 58.1 & Permissible & 96.1 & Unsuitable & 6.8 & Excellent & -3.3 & Good \\
\hline 6 & 756 & 1685.5 & 62.3 & Doubtful & 95.1 & Unsuitable & 5.7 & Excellent & -0.6 & Good \\
\hline 7 & 1015 & 2270.0 & 67.8 & Doubtful & 95.7 & Unsuitable & 8.3 & Excellent & 0.1 & Good \\
\hline 8 & 206 & 462.0 & 54.1 & Permissible & 94.0 & Unsuitable & 2.6 & Excellent & 0.2 & Good \\
\hline 9 & 865 & 1927.5 & 57.4 & Permissible & 95.0 & Unsuitable & 5.1 & Excellent & -0.3 & Good \\
\hline 10 & 878 & 1961.0 & 62.3 & Doubtful & 94.5 & Unsuitable & 6.2 & Excellent & 2.9 & Unsuitable \\
\hline 11 & 1082 & 2400.0 & 55.2 & Permissible & 95.6 & Unsuitable & 5.4 & Excellent & -3.0 & Good \\
\hline 12 & 595 & 1355.0 & 52.3 & Permissible & 95.8 & Unsuitable & 3.8 & Excellent & -0.6 & Good \\
\hline 13 & 703 & 1589.5 & 56.1 & Permissible & 94.8 & Unsuitable & 4.7 & Excellent & 0.6 & Good \\
\hline 14 & 1154 & 2580.0 & 56.4 & Permissible & 95.8 & Unsuitable & 5.9 & Excellent & -0.5 & Good \\
\hline 15 & 657 & 1454.0 & 67.8 & Doubtful & 94.8 & Unsuitable & 6.4 & Excellent & 1.7 & Doubtful \\
\hline 16 & 730 & 1625.5 & 59.3 & Permissible & 94.3 & Unsuitable & 5.6 & Excellent & -0.8 & Good \\
\hline 17 & 788 & 1870.0 & 50.5 & Permissible & 94.4 & Unsuitable & 4.5 & Excellent & 0.7 & Good \\
\hline 18 & 1040 & 2535.0 & 58.2 & Permissible & 94.6 & Unsuitable & 6.2 & Excellent & 1.2 & Good \\
\hline 19 & 2740 & 5515.0 & 68.8 & Doubtful & 92.9 & Unsuitable & 14.4 & Good & -3.7 & Good \\
\hline 20 & 569 & 1261.5 & 73.2 & Doubtful & 90.7 & Unsuitable & 7.2 & Excellent & 0.5 & Good \\
\hline 21 & 3400 & 6617.5 & 70.0 & Doubtful & 93.1 & Unsuitable & 16.1 & Good & -7.1 & Good \\
\hline 22 & 3650 & 7155.0 & 62.4 & Doubtful & 94.8 & Unsuitable & 14.4 & Good & -12.2 & Good \\
\hline 23 & 2520 & 4715.0 & 69.9 & Doubtful & 92.9 & Unsuitable & 15.7 & Good & -1.8 & Good \\
\hline 24 & 3250 & 6325.0 & 64.1 & Doubtful & 93.6 & Unsuitable & 14.9 & Good & -7.0 & Good \\
\hline 25 & 2700 & 5210.0 & 64.4 & Doubtful & 100.0 & Unsuitable & 13.8 & Good & -4.8 & Good \\
\hline
\end{tabular}




\section{DISCUSSION}

The $\mathrm{pH}$ range of groundwater in the study area is higher than 7 and within the limit of alkaline nature. High $\mathrm{pH}$ could be possibly related to the presence of sodium, calcium, magnesium and bicarbonate ions in groundwater. Such water belonging to this range of $\mathrm{pH}$ can be used for irrigation. The concentrations of both $\mathrm{Ca}^{+2}$ and $\mathrm{K}^{+}$in groundwater of the study area were far below the maximum concentration compared to 20 and 2 meq $\mathrm{L}^{-1}$, respectively as the maximum recommended limit. However, the $\mathrm{Na}^{+}$concentration in groundwater exceeded the recommended limit of 40 meq $\mathrm{L}^{-1}$ in three samples. Excessive $\mathrm{Na}^{+}$in the collected samples might be ascribed to evaporation of irrigated water. About $88 \%$ of water wells in the investigated area can be used for long term irrigation without any harmful effects on soils and crops. At the same time, 10 out of 25 samples exceeded the allowance limit of $\mathrm{Mg}^{+2}$ of $5 \mathrm{meq} \mathrm{L}^{-1}$. It is observed that the excess of $\mathrm{Na}^{+}$and $\mathrm{Mg}^{+2}$ are concentrated to the west of the study area as the groundwater moves from east to west. This could be related to weathering of Oman Mountains.

Despite having nil amount of carbonate $\left(\mathrm{CO}_{3}^{-2}\right)$ in this groundwater, the concentration of bicarbonate $\left(\mathrm{HCO}_{3}{ }^{-}\right)$in all samples was within the allowance limit except sample no. 19 which exceeded the recommended limit of 10 meq $\mathrm{L}^{-1}$. Therefore, groundwater of the study area can be used effectively for irrigation.

Groundwater of the study area was assessed to determine the suitability of groundwater of the region for irrigation. High salinity in irrigation water is toxic to plants and may pose a salinity hazard and soils with high concentrations of salts may induce physiological drought conditions (Nishanthiny et al., 2010). The salinity of water is measured and classified according to Sadashivaiah et al. (2008). Based on EC classification, about $44 \%$ of the collected samples (11 samples out of 25) are classified as very high salinity which is unsuitable for irrigation, but the remaining $56 \%$ (14 samples) is characterized by high salinity which is doubtful to be used for irrigation. Such high salinity in irrigation water might affect the osmotic pressure of the soil solution. It is noticed that, the salinity of groundwater increases towards the west of the study area away from the recharge area suggesting that salinity accumulates as the groundwater travel from recharge to discharge area.
The calculated SSP for groundwater in the investigated area showed that about $44 \%$ of the samples (11 samples out of 25) are grouped under permissible class (SSP from 40 to $60 \%$ ) and $56 \%$ of the samples (14 samples) are grouped under doubtful class (SSP from 60 to $80 \%$ ). Most of the samples are problematic for irrigation purposes in the study area. However, most of the groundwater in the study area based on SAR calcuation is classified as good (24\%) to excellent (76\%) for crop production. On the other hand, the calculated magnesium hazard indicated that groundwater are not suitable for irrigation purposes as MAR exceeded 50\% and could cause harmful effect to the soil.

There is a tendency for $\mathrm{Ca}^{+2}$ and $\mathrm{Mg}^{+2}$ to precipitate in water having high concentration of bicarbonate. Consequently, the proportion of sodium in water is increased in the form of sodium bicarbonate (Sadashivaiah et al., 2008). All samples have RSC less than 1.25 except three samples (samples no. 3, 10 and 14) and are considered safe for irrigation uses, but one sample (sample no. 10) is unsuitable for irrigation purposes as RSC is 2.9. Groundwater from wells no. 3 and 14 can be used with good management and salinity monitoring.

Relationships between different quality parameters were determined (Table 3). It is observed that a slight good and positive relationship of EC with SAR and RSC with $r^{2}$ of 0.83 and 0.76 , respectively. This reveals that sodium accumulates in groundwater due to heavy use of agricultural practices in the area.

The relationship between SAR (meq/L) and EC $(\mu \mathrm{S} / \mathrm{cm})$ is plotted with $\mathrm{R}^{2}$ of 0.8 (Fig. 2). The samples distribution in the plot indicates that there are two groupings of the samples. The first group, located to the east of the study area, is characterized by low salinity and low SAR which is equivalent to $\mathrm{C} 3-\mathrm{S} 1$ class in Wilcox diagram. Such class is of high salinity and low sodium content. Consequently, special management for salinity control is required and plants with good salt tolerance should be selected. The water of this class is acceptable for irrigation of most crops in most soils. The second group of the samples, located to the west of the study area, is characterized by high salinity and high SAR which is equivalent to C4-S3 class of Wilcox diagram implying that the groundwater is not suitable for irrigation under ordinary conditions, but may be used in soils that are permeable with adequate drainage and application of excess irrigation water in order to allow leaching. Such water can be considered for very-salt tolerant crops. 


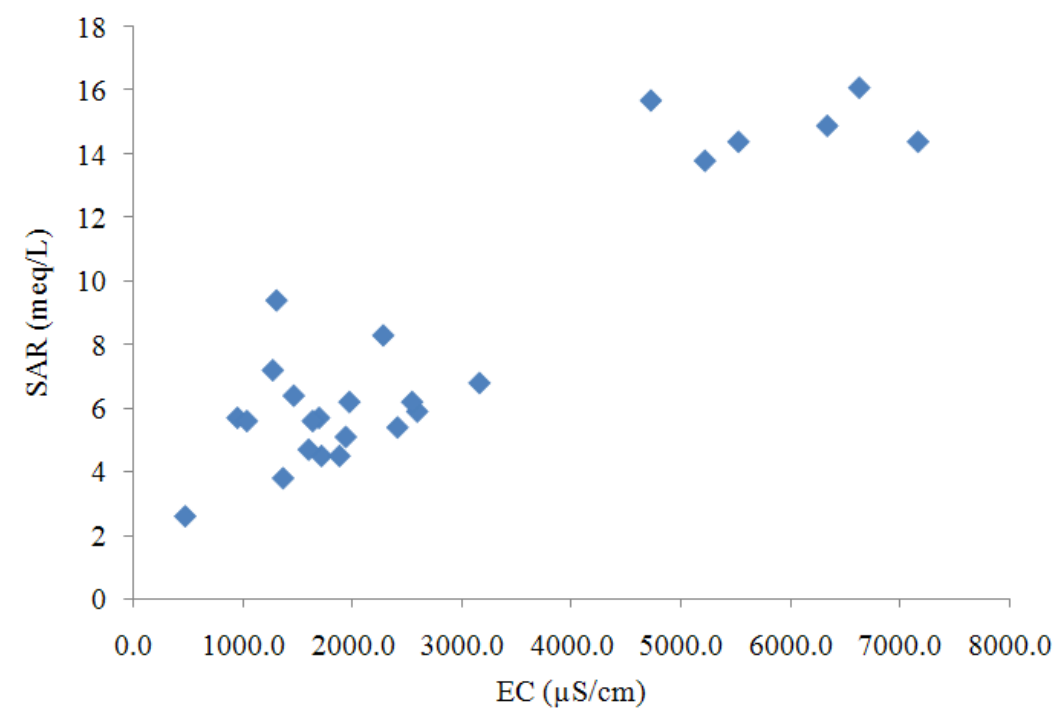

Fig. 2. EC Vs. SAR plot for collected groundwater samples

Table 3. Relationship between water quality parameters

\begin{tabular}{llllll}
\hline Parameters & EC & MAR & SAR & RSC & SSP \\
\hline EC & --- & 0.068 & 0.83 & 0.76 & 0.04 \\
MAR & & & 0.0002 & 0.0505 & \\
SAR & & & --- & & \\
RSC & & & & --- & \\
SSP & & 0.35 & 0.3 & 0.002 & --- \\
\hline
\end{tabular}

\section{CONCLUSION}

Investigating the suitability of groundwater in the study area was tested based on salinity hazard (EC), sodium hazard (SAR and SSP), magnesium hazard (MAR) and bicarbonate hazard (RSC). Excess of $\mathrm{Na}^{+}$ and $\mathrm{Mg}^{+2}$ may be ascribed to the weathering of Oman Mountains which is located to the east of the study area. The results showed that about $88 \%$ of groundwater from the study area can be used for long-term irrigation without any effects on the crop production.

The analyses based on salinity hazard showed that about $44 \%$ of collected groundwater samples from the entire region are grouped as very high salinity and are not suitable for irrigation and about $56 \%$ are grouped as high salinity which are doubtful to be used for irrigation. Such high salinity in irrigation water might affect the osmotic pressure of the soil solution. However, using SSP classification, about $44 \%$ of collected samples are permissible for the irrigation uses and about $56 \%$ of the collected groundwater samples are doubt to be used for irrigation practices. The SAR classification indicates that the groundwater of the study area ranges from good to excellent for crop production, while the calculated magnesium hazard indicates that all samples are not suitable for irrigation purposes.

There are two groups of samples based on SAR-EC relationship. The first group is mainly of high salinity and low sodium content. This type of water requires special attention with selection of plants of good salt tolerance and the water can be accepted for irrigation of most crops in most soils. The second group of groundwater is not suitable for irrigation under ordinary conditions, but may be used under special conditions.

In conclusion, it is highly recommended to monitor the quality of soil and irrigation water based on regular basis to avoid problems associated with crop production. Future research must focus on understanding the effect of agriculture practices on the quality of groundwater in neighboring areas. Remote sensing and Geographic Information System (GIS) may use as a tool to identify the extension of irrigated areas and can help to plan future research.

\section{REFERENCES}

Appelo, C.A.J. and D. Postma, 1999. Geochemistry, groundwater and pollution. Fourth Print, A. A. Balkema, Rotterdam, Netherlands, pp: 536. 
Clesceri, L.S., A.E. Greenberg and R.R. Trussell, 1989. Standard Methods for the Examination of Water and Waste Water. 17th Edn., American Public Health Association, Washington DC., USA., pp: 175.

Domenico, P.A. and F.W. Schwartz, 1990. Physical and Chemical Hydrogeology. 1st Edn., John Wiley and Sons, New York, ISBN-10: 047150744X, pp: 824.

Eaton, F.M., 1950. Significance of carbonates in irrigation waters. Soil Sci., 95: 125-133.

Grattan, S.R., 2002. Irrigation water salinity and crop production. Proceedings of the Agriculture and Natural Resources in partnership with Natural Resources Conservation Service (CS '02), University of California Farm Water Quality Planning (FWQP), Reference Sheet 9.10.

Hakim, M.A., A.S. Juraimi, M. Begum, M. Hasanuzzaman and M.K. Uddin et al., 2009. Suitability evaluation of groundwater for irrigation, drinking and industrial purposes. Am. J. Environ. Sci., 5: 413-419. DOI: 10.3844/ajessp.2009.413.419

Ibrahim, A.K., S.A. Ibrahim and S. Mustapha, 2012. Suitability of groundwater for irrigation use in nafada, nafada local government area, gombe state. J. Applied Phytotechnol. Environm. Sanitat., 1: 173-179.

Kendaragama, K.M.A., 2000. Quality of agro well water in the Dryzone-A case study in the Anuradapura district. J. Soil Sci. Society Srilanka, 12: 26-33.
Nishanthiny, S.C., M. Thushyanthy, T. Barathithasan and S. Saravanan, 2010. Irrigation water quality based on hydro chemical analysis, Jaffna, Sri Lanka. Am. Eurasain J. Agric. Environ. Sci., 7: 100-102.

RSL, 1954. Diagnosis and Improvement of Saline and Alkali Soils. 1st Edn., U.S. Dept. of Agriculture, Washington, pp: 160.

Sadashivaiah, C., C.R. Ramakrishnaiah and G. Ranganna, 2008. Hydrochemical analysis and evaluation of groundwater quality in TumkurTaluk, Karnataka State, India. Intl. J. Environ. Res. Public Health, 5: 158-164. DOI: 10.3390/ijerph5030158

Shiklomanov, I.A., 1993. World Freshwater Resources. In: Water in Crisis: A Guide to the World's Freshwater Resources. Gleick, P.H., (Ed.,), New York, Oxford University Press.

Szabolcs, I. and C. Darab, 1964. The influence of irrigation water of high sodium carbonates content of soils. Proceedings of the 8th International congress of ISSS, pp: 803-812.

Todd, D.K., 1980. Groundwater Hydrology. 2nd Edn., John Wiley and Sons. Inc., New York, pp: 535. 